\title{
The effect of creep feed and diet complexity on growth performance in suckling and weaned pigs
}

\author{
Efecto de la dieta de pre-iniciación y su complejidad sobre el crecimiento de cerdos lactantes y destetados \\ Efeito da dieta pré-iniciada e sua complexidade no crescimento de porcos lactantes e desmamados
}

Paige K Isensee $\mathbb{D}^{\text {; }}$; Sarah E Albers $\left(\mathbb{D}\right.$; Lindsey G Wichman ${ }^{D}$; Autumn L Thoma $\mathbb{D}$; Young D Jang*(D).

Department of Animal and Food Science, University of Wisconsin-River Falls, River Falls, WI 54022, USA.

To cite this article:

Isensee PK, Albers SE, Wichman LG, Thoma AL, Jang YD. The effect of creep feed and diet complexity on growth performance in suckling and weaned pigs. Rev Colomb Cienc Pecu 2020; 33(3): 159-171. DOI: https://doi.org/10.17533/udea.rccp.v33n3a04

\begin{abstract}
Background: Creep feed is offered to suckling piglets to introduce solid feed and provide extra nutrients in late lactation. However, the effect of creep feed is inconsistent; there is little information about the effect of creep diet complexity on piglet performance. Objective: Two experiments were conducted to evaluate the effect of creep feed and its complexity on growth performance of suckling and weaned pigs. Methods: In Exp. 1, eight litters (average $19.9 \pm 1.1 \mathrm{~d}$ of age; initial piglet weight: $6.74 \pm 1.2 \mathrm{~kg}$ ) were allotted to two dietary treatments considering breed, litter size and weight, as follows: no creep feed ( $\mathrm{n}=3$ ) and creep feed ( $\mathrm{n}=5$; offered for 8 days before weaning). At weaning ( 28 of age), the pigs were divided into three treatments (6 pigs/pen, 3 replicates; initial body weight: $9.66 \pm 0.34 \mathrm{~kg}$ ) balanced by gender, body weight, and breed, as follows: creep feed eaters, creep feed non-eaters, and no creep feed. In Exp. 2, two different types of creep feed were offered to suckling piglets (initial piglet weight: $3.79 \pm 0.55 \mathrm{~kg}$ ) in seven litters from d 12 of age (average $12.0 \pm 1.3 \mathrm{~d}$ of age) to weaning (d 25 of age). Treatments were: $\mathrm{HCF}(\mathrm{n}=4)$ : highly-complex creep diet containing $3 \%$ fish meal, $2.4 \%$ blood meal, and $15 \%$ whey; and 2) LCF ( $n=3)$ : lowly-complex creep diet without the mentioned ingredients. At weaning, only eater pigs were divided into 2 treatments ( 6 pigs/pen, 3 replicates; initial body weight: $7.53 \pm 0.97 \mathrm{~kg}$ ) balanced by gender, breed and body weight as follows: HCF eaters and LCF eaters. In both experiments, creep feed was mixed with $1 \% \mathrm{Cr}_{2} \mathrm{O}_{3}$ to measure fecal color for eater/non-eater categorization and the pigs were fed a common nursery diet for 21 days. Results: In both experiments, there were no differences on piglet weaning weight and overall nursery growth performance among the treatments. In Exp. 2, the creep feed intake and percentage of eaters per litter were not different between the HCF and LCF treatments, whereas the HCF eaters tended to have a greater average daily gain $(\mathrm{p}=0.08)$ and gain to feed ratio $(\mathrm{p}=0.09)$ than the LCF eaters during $\mathrm{d} 7$-14 postweaning. Conclusion: Creep feed did not affect overall piglet growth in suckling and nursery phases, but its complexity might affect pig growth in the early nursery phase.
\end{abstract}

Keywords: complex diet; creep feed; diet complexity; growth performance; litter performance; nursery diet; piglet; suckling; weaning.

Received: December 25, 2019; accepted: April 8, 2020

*Corresponding Author. 410 S. $3^{\text {rd }}$ st. 319 Ag Science Building, River Falls, WI 54022, USA. Tel.: +1-715-425-4385. Fax: +1-715-425-3785. Email: youngdal.jang@uwrf.edu 


\section{Resumen}

Antecedentes: El alimento de pre-iniciación se ofrece a los lechones lactantes para introducir la alimentación sólida y proporcionar nutrientes adicionales durante la lactancia tardía. Sin embargo, sus efectos son inconsistentes y hay poca información sobre el efecto de la complejidad de la dieta de pre-iniciación sobre el rendimiento de los cerdos. Objetivo: Se realizaron dos experimentos para evaluar el efecto del suministro de pre-iniciador y la complejidad del mismo sobre el crecimiento de lechones y cerdos destetados. Métodos: En el Exp. 1, ocho camadas (promedio 19,9 $\pm 1.1 \mathrm{~d}$ de edad; peso inicial: $6,74 \pm 1,2 \mathrm{~kg}$ ) se asignaron a dos tratamientos con base en raza, tamaño de camada, y peso, de la siguiente manera: $\sin$ suministro $(\mathrm{n}=3)$ y con suministro de pre-iniciador $(\mathrm{n}=5$; ofrecido durante 8 días antes del destete). Al destete ( 28 de edad) los cerdos se dividieron en 3 tratamientos ( 6 cerdos/corral y 3 réplicas; peso inicial: 9,66 $\pm 0,34 \mathrm{~kg}$ ) balanceados por género, peso y raza, de la siguiente manera: consumidores de pre-iniciador, no consumidores de pre-iniciación, y sin suministro de pre-iniciación. En el Exp. 2 se ofrecieron dos tipos diferentes de pre-iniciador a los cerditos lactantes (peso inicial del lechón: $3,79 \pm 0,55 \mathrm{~kg}$ ) en siete camadas desde el día 12 de edad (promedio 12,0 $\pm 1,3$ días de edad) hasta el destete (día 25 de edad). Los tratamientos fueron: HCF (n=4): dieta de pre-iniciación de alta complejidad conteniendo $3 \%$ de harina de pescado, 2,4\% de harina de sangre y $15 \%$ de suero de leche; y 2) LCF ( $n=3)$ : dieta de pre-iniciación de baja complejidad, sin esos ingredientes. $\mathrm{Al}$ destete, solo los cerdos que consumieron pre-iniciador se dividieron en 2 tratamientos $(6$ cerdos/corral, 3 repeticiones; peso corporal inicial: 7,53 $\pm 0,97 \mathrm{~kg}$ ) balanceados por género, raza y peso, de la siguiente manera: consumidores de HCF o de LCF. En ambos experimentos el pre-iniciador se mezcló con $\mathrm{Cr}_{2} \mathrm{O}_{3}$ al $1 \%$ para medir el color fecal y categorizar los consumidores/ no consumidores, y los cerdos se alimentaron con una dieta común de iniciación durante 21 días. Resultados: En ambos experimentos no hubo diferencias en el peso al destete de los lechones y el rendimiento general de crecimiento en re-cría entre tratamientos. En el Exp. 2, la ingesta de pre-iniciador y el porcentaje de cerdos consumidores por camada no fueron diferentes entre los HCF y LCF, mientras que los consumidores de HCF tendieron a tener mayor ganancia diaria $(\mathrm{p}=0,08)$ y mayor relación ganancia/alimento $(\mathrm{p}=0,09)$ que los consumidores de LCF durante los días 7-14 pos-destete. Conclusión: el pre-iniciador no afecta el crecimiento general de los lechones en las fases de lactancia y re-cría, pero la complejidad de la dieta podría afectar el crecimiento de los cerditos al inicio de la re-cría.

Palabras clave: cerdo lactante; complejidad de la dieta; destete; dieta compleja; dieta de re-cría; mamón; pre-iniciador; rendimiento de crecimiento; rendimiento de la camada.

\section{Resumo}

Antecedentes: A alimentação por fluência é oferecida aos leitões para introduzir alimentos sólidos e fornecer nutrientes extras no final da lactação. No entanto, o efeito ainda é inconsistente e há poucas informações sobre o efeito da complexidade da dieta de fluência no desempenho dos leitões. Objetivo: Dois experimentos foram conduzidos para avaliar o efeito da alimentação por fluência e a complexidade da dieta no desempenho do crescimento de porcos em aleitamento e desmame. Métodos: Em Exp. 1, oito ninhadas (média de 19,9 $\pm 1,1 \mathrm{~d}$ de idade; peso inicial do leitão: 6,74 $\pm 1,2 \mathrm{~kg}$ ) foram distribuídos em 2 tratamentos com base na raça, tamanho e peso da ninhada, da seguinte forma: ausência de ração $(n=3)$ e ração por creep $(n=5$; oferecido por 8 dias antes do desmame). No desmame (d 28 anos de idade), os porcos foram divididos em 3 tratamentos (6 porcos/caneta, 3 repetições; peso corporal inicial: $9,66 \pm 0,34 \mathrm{~kg}$ ) balanceados com gênero, peso corporal e raça, como a seguir: comedores de ração, creep feed não comedores, e creep feed. Em Exp. 2, foram oferecidos dois tipos diferentes de ração para leitões (peso inicial dos leitões: $3,79 \pm 0,55 \mathrm{~kg}$ ) em sete ninhadas de 12 anos de idade (média 12,0 $\pm 1,3$ dias) até o desmame (25 anos). Os tratamentos foram: $\mathrm{HCF}(\mathrm{n}=4)$ : dieta de fluência de alta complexidade contendo $3 \%$ de farinha de peixe, $2,4 \%$ de farinha de sangue e $15 \%$ de soro de leite; e 2) LCF ( $n=3)$ : dieta de fluência de baixa complexidade sem esses ingredientes. No desmame, apenas os porcos comedores foram divididos em 2 tratamentos (6 porcos/caneta, 3 repetições; peso corporal inicial: 7,53 \pm $0,97 \mathrm{~kg}$ ) balanceados com gênero, raça e peso corporal da seguinte forma: comedores de HCF e comedores de LCF. Em ambos os experimentos, a alimentação fluida foi misturada com $1 \% \mathrm{de}_{2} \mathrm{O}_{3}$ para medir a cor fecal para categorização de comedor/ não comedor e os porcos foram alimentados com uma dieta comum durante 21 dias. Resultados: Nos dois experimentos, não houve diferenças no peso ao desmame dos leitões e no desempenho geral do crescimento do viveiro entre os tratamentos. Em Exp. 2, o consumo de ração por creep e a porcentagem de comedores por ninhada não foram diferentes entre os tratamentos de HCF e LCF, enquanto os comedores de HCF tenderam a ter um maior ganho médio diário $(\mathrm{p}=0,08)$ e uma taxa de ganho para alimentação $(\mathrm{p}=0,09)$ do que os comedores de LCF durante d 7-14 pós-desmame. Conclusão: A alimentação por fluência não afetou o crescimento geral de leitões nas fases de amamentação e viveiro, mas a complexidade da dieta pode afetar o crescimento de leitões na fase inicial do viveiro.

Palavras-chave: complexidade da dieta; desempenho da camada; desempenho de crescimento; desmame; dieta complexa; dieta de iniciação; dieta pré-iniciada; leitão; mamar. 


\section{Introduction}

Weaning is the most stressful event that pigs face in their life, and may result in postweaning growth lag and diarrhea associated with pathogenic bacteria. The piglet's digestive system is not fully developed, making them very vulnerable while they experience environmental, social, and nutritional stressors (Palmer and Hulland, 1965; Cera et al., 1990). The postweaning growth lag reflects reduced or negative growth rate when piglets cease eating after weaning; ultimately, becoming more susceptible to pathogens (Varley and Wiseman, 2001).

Creep feeding is a management strategy that supplies extra nutrients to suckling pigs during the late lactation period, and provides an adaption period before weaning as newly weaned piglets may not be able to fully digest nutrients from plant-based diets (Cabrera et al., 2013). The effects of creep feeding during lactation are beneficial to increase postweaning feed intake, resulting in improved growth rate. Kuller et al. (2007) found a positive relationship between litter creep feed intake and feed intake and weight gain in the first week postweaning. Heo et al. (2018) reported that creep feed containing highly digestible feed ingredients improved growth performance of piglets during the creep feeding period, whereas a familiarity of pigs to the diet improved growth performance after weaning.

However, the effectiveness of creep feeding in pigs is still inconsistent due to low creep feed consumption and a wide variation in creep feed consumption among individual littermates (Fraser et al., 1994; Kuller et al., 2007; Sulabo et al., 2010a). Also, there is little information about the effect of creep diet complexity on pre- and postweaning growth performance of pigs and how quickly these piglets adapt to the nursery diet when creep feeds of different complexity are offered during the suckling period.

Therefore, the objectives of this study were to evaluate the effect of creep feed availability and complexity on piglet growth performance during suckling and nursery periods. Experiment 1 was conducted to evaluate the effect of creep feeding in suckling and nursery pigs. Experiment 2 evaluated the effect of creep feed and diet complexity.

\section{Materials and Methods}

\section{Ethical Considerations}

All procedures used in this study were approved by the Institutional Animal Care and Use Committee of University of Wisconsin-River Falls (Protocol \#18-19-5). The experiment was conducted in the farrowing and nursery facilities at Mann Valley Farm of University of WisconsinRiver Falls (WI, USA).

\section{Animals and experimental designs}

In Experiment 1, eight litters with a total of 75 piglets (Yorkshire $\times$ Duroc, Yorkshire $\times$ Yorkshire; initial piglet weight: $6.74 \pm 1.2 \mathrm{~kg}$ ) on $\mathrm{d} 20$ of age $(19.9 \pm 1.1 \mathrm{~d})$ were allotted to 2 treatments based on breed, litter size, and litter weight, as follows: 1 ) No creep feed ( $n=3$ litters), and 2) Creep feed ( $n=5$ litters): creep feed offered from d 20 of age to weaning ( $28 \mathrm{~d}$ of age) for 8 days. During pre-weaning, the color of the feces was measured from all pigs to categorize them as eaters or non-eaters by including $1 \% \mathrm{Cr}_{2} \mathrm{O}_{3}$ (Beantown Chemical, Hudson, NH, USA) in the creep feed as a color indicator. At weaning, the pigs were divided into three treatment groups (a total of 54 pigs with 6 pigs/pen in 3 replicates; initial body weight: $9.66 \pm 0.34 \mathrm{~kg}$ ) based on category balanced by gender, breed, and weight, for a 21-d feeding trial during the nursery period. The nursery treatments were: 1 ) creep feed eaters in lactation, 2) creep feed noneaters in lactation, and 3) creep feed not offered in lactation. During postweaning, feces color was measured from all pigs to categorize them as nursery feed eaters or non-eaters by including $1 \% \mathrm{Fe}_{2} \mathrm{O}_{3}$ (Beantown Chemical, Hudson, $\mathrm{NH}$, USA) in the diet as a color indicator from weaning until all pigs became eaters.

In Experiment 2, seven litters with a total of 66 piglets (Yorkshire $\times$ Duroc, Yorkshire $\times$ Yorkshire; initial piglet weight: $3.79 \pm 0.55 \mathrm{~kg}$ ) on $\mathrm{d} 12$ of age $(12.0 \pm 1.3 \mathrm{~d})$ were allotted to 
2 treatments based on breed, litter size, and litter weight, as follows: HCF ( $n=4$ litters): highly-complex creep diet with $3 \%$ fish meal, $2.4 \%$ blood meal, and 15\% whey, and LCF ( $n=3$ litters): lowly-complex creep diet without those ingredients. During the period of creep feeding from d 12 of age to weaning (average $d$ 25 of age) for 13 days, feces color was measured from all pigs to categorize them as eaters or non-eaters by including $1 \% \mathrm{Cr}_{2} \mathrm{O}_{3}$ (Beantown Chemical, Hudson, NH, USA) in the diet as a color indicator. At weaning, because of low number of non-eater pigs, only eaters were divided into 2 treatments (a total of 36 pigs with 6 pigs/pen, with 3 replicates; initial BW: $7.53 \pm 0.97 \mathrm{~kg}$ ), as follows: 1) HCF eaters; and 2) LCF eaters. Feces color was measured from all pigs to categorize them as nursery feed eaters or non-eaters by including $1 \% \mathrm{Fe}_{2} \mathrm{O}_{3}$ (Beantown Chemical, Hudson, NH, USA) in the diet as a color indicator from weaning until all pigs became eaters.

\section{Diets and housing}

Creep feed. In Experiment 1, the creep feed offered was a corn-soybean meal-based diet containing fish meal (2.5\%), blood meal (2.5\%), and whey $(15 \%)$, with $1 \% \mathrm{Cr}_{2} \mathrm{O}_{3}$ added as a color indicator (Table 1). All essential nutrients were in slight excess of the NRC (2012) requirement estimates.

In Experiment 2, the HCF diet was prepared as a corn-soybean meal-based diet containing fish meal (3\%), blood meal (2.4\%), and whey (15\%) and the LCF diet was prepared by replacing all fish meal, blood meal, and whey in the HCF diet with corn (Table 2). This resulted in a reduction of $4 \%$ crude protein and $0.4 \%$ standardized ileal digestible lysine content. Both diets were mixed with $1 \% \mathrm{Cr}_{2} \mathrm{O}_{3}$ as a color indicator. All essential nutrients in the HCF diet were in slight excess of the NRC (2012) requirement estimates, whereas those in the LCF diet did not meet the NRC (2012) requirement estimates as fish meal, blood meal, and whey were replaced with corn from the HCF diet for the purpose of lowering nutrient levels and complexity in the LCF diet.

All suckling pigs in Experiments 1 and 2 were housed with their dam, given free access to water and creep feed in raised-deck farrowing crates $\left(1.52 \times 2.13 \mathrm{~m}^{2}\right)$, with tenderfoot or woven-wire flooring in an environmentally controlled farrowing facility.

Table 1. Diet formulation and calculated chemical composition (Experiment 1).

\begin{tabular}{|c|c|}
\hline Ingredients & $\%$ \\
\hline Corn & 47.35 \\
\hline Soybean meal (48\% CP) & 19.30 \\
\hline Fish meal & 2.50 \\
\hline Blood meal & 2.50 \\
\hline Whey, dried & 15.00 \\
\hline Oats & 2.50 \\
\hline Soy oil & 3.20 \\
\hline L-Lysine $\cdot \mathrm{HCl}$ & 0.15 \\
\hline Trace mineral ${ }^{l}$ and vitamin premix ${ }^{2}$ & 7.50 \\
\hline Calculated chemical composition & \\
\hline Metabolizable energy, $\mathrm{kcal} / \mathrm{kg}$ & 3,363 \\
\hline Crude protein, $\%$ & 20.49 \\
\hline $\mathrm{SID}^{3}$ lysine, $\%$ & 1.56 \\
\hline SID methionine + cysteine, $\%$ & 0.82 \\
\hline Total $\mathrm{Ca}, \%$ & 1.11 \\
\hline $\mathrm{STTD}^{3} \mathrm{P}, \%$ & 0.53 \\
\hline \multicolumn{2}{|c|}{$\begin{array}{l}{ }^{1} \text { The trace mineral premix supplied the following per kilogram } \\
\text { of diet: } 66 \mathrm{mg} \mathrm{Mn} \text { (as manganese sulfate), } 187 \mathrm{mg} \mathrm{Fe} \text { (as } \\
\text { ferrous sulfate), } 375 \mathrm{mg} \mathrm{Zn} \text { (as zinc sulfate), } 300 \mathrm{mg} \mathrm{Cu} \text { (as } \\
\text { copper sulfate), } 1.13 \mathrm{mg} \text { I (as ethylenediamine dihydroiodide), } \\
\text { and } 0.45 \mathrm{mg} \mathrm{Se} \text { (as sodium selenite) with } 0.60 \% \text { salt. } \\
{ }^{2} \text { The vitamin premix supplied the following per kilogram } \\
\text { of diet: } 16,500 \mathrm{IU} \text { vitamin } \mathrm{A}, 2,640 \mathrm{IU} \text { vitamin } \mathrm{D}_{3}, 198 \mathrm{IU} \\
\text { vitamin } \mathrm{E}, 3.3 \mathrm{mg} \text { vitamin } \mathrm{K}, 53 \mathrm{mg} \text { vitamin } \mathrm{B}_{12}, 15 \mathrm{mg} \\
\text { riboflavin, } 99 \mathrm{mg} \text { pantothenic acid, } 75 \mathrm{mg} \text { niacin, } 2 \mathrm{mg} \text { folic } \\
\text { acid, } 4.2 \mathrm{mg} \text { vitamin } \mathrm{B}_{6}, 3.0 \mathrm{mg} \text { thiamin, and } 0.13 \mathrm{mg} \text { biotin. } \\
{ }^{3} \mathrm{SID}=\text { standardized ileal digestible, STTD }=\text { standardized } \\
\text { total tract digestible. }\end{array}$} \\
\hline
\end{tabular}


Table 2. Diet formulation and calculated chemical composition (Experiment 2).

\begin{tabular}{|c|c|c|}
\hline Ingredients & HCF & LCF \\
\hline Corn & 52.54 & 72.94 \\
\hline Soybean meal (48\% CP) & 18.30 & 18.30 \\
\hline Fish meal & 3.00 & - \\
\hline Blood meal & 2.40 & - \\
\hline Whey, dried & 15.00 & - \\
\hline Soy oil & 2.60 & 2.60 \\
\hline L-isoleucine & 0.08 & 0.08 \\
\hline L-valine & 0.04 & 0.04 \\
\hline L-tryptophan & 0.04 & 0.04 \\
\hline Trace mineral $^{l}$ and vitamin premix ${ }^{2}$ & 6.00 & 6.00 \\
\hline \multicolumn{3}{|l|}{ Calculated chemical composition } \\
\hline Metabolizable energy, $\mathrm{kcal} / \mathrm{kg}$ & 3,403 & 3,387 \\
\hline Crude protein, $\%$ & 20.02 & 15.86 \\
\hline SID $^{3}$ lysine, $\%$ & 1.35 & 0.96 \\
\hline SID methionine + cysteine, $\%$ & 0.78 & 0.68 \\
\hline Total Ca, \% & 0.97 & 0.73 \\
\hline $\mathrm{STTD}^{3} \mathrm{P}, \%$ & 0.49 & 0.34 \\
\hline
\end{tabular}

${ }^{I}$ The trace mineral premix supplied the following per kilogram of diet: $53 \mathrm{mg} \mathrm{Mn} \mathrm{(as} \mathrm{manganese} \mathrm{sulfate),} 150 \mathrm{mg} \mathrm{Fe}$ (as ferrous sulfate), $300 \mathrm{mg} \mathrm{Zn}$ (as zinc sulfate), $240 \mathrm{mg} \mathrm{Cu}$ (as copper sulfate), $0.9 \mathrm{mg}$ I (as ethylenediamine dihydroiodide), and $0.36 \mathrm{mg}$ Se (as sodium selenite) with $0.48 \%$ salt. ${ }^{2}$ The vitamin premix supplied the following per kilogram of diet: 13,200 IU vitamin A, 2,112 IU vitamin $\mathrm{D}_{3}, 158 \mathrm{IU}$ vitamin $\mathrm{E}, 2.6 \mathrm{mg}$ vitamin $\mathrm{K}, 42.2 \mathrm{mg}$ vitamin $\mathrm{B}_{12}, 12.0 \mathrm{mg}$ riboflavin, $79 \mathrm{mg}$ pantothenic acid, $60 \mathrm{mg}$ niacin, $1.6 \mathrm{mg}$ folic acid, $3.4 \mathrm{mg}$ vitamin $\mathrm{B}_{6}, 2.4 \mathrm{mg}$ thiamin, and $0.11 \mathrm{mg}$ biotin. ${ }^{3} \mathrm{SID}=$ standardized ileal digestible, STTD $=$ standardized total tract digestible.

Nursery feed. In Experiment 1, all pigs were fed ad libitum a standard nursery diet used during the creep feeding period as the creep feed (Table 1), and given free access to water for 21 days. All essential nutrients were in slight excess of the NRC (2012) requirement estimates. In Experiment 2, the HCF diet were fed commonly to all pigs ad libitum (Table 2) and given free access to water for 21 days. All essential nutrients were in slight excess of the NRC (2012) requirement estimates. The nursery diets in Experiments 1 and 2 were mixed with $1 \% \mathrm{Fe}_{2} \mathrm{O}_{3}$ as a color indicator. In Experiments 1 and 2, all pigs were housed in raised-deck nursery pens $\left(1.32 \times 1.63 \mathrm{~m}^{2}\right)$ with plastic or woven-wire flooring in an environmentally controlled nursery facility.

\section{Data collection}

In Experiment 1, all pigs were weighed at initial (average d 20 of age), d 5 after starting creep feed, weaning (average d 28 of age), and d 7, 14, and 21 postweaning to evaluate growth performance. In Experiment 2, all pigs were weighed at initial (average d 12 of age), d 4, 7 after starting creep feed, weaning (average d 25 of age), d 7, 14, and 21 postweaning. In both experiments, circular feeders were replenished daily, and creep feed and nursery feed disappearance were measured when the pigs were weighed. Feed provided and feed waste were recorded. A clean pan $\left(45.7 \times 66.0 \mathrm{~cm}^{2}\right)$ was placed underneath each farrowing crate to collect the creep feed wasted and cleaned every day after measuring the waste. The feed waste was measured daily in the morning by weighing the pan with feed waste and subtracting the empty pan weight. Average daily gain (ADG) in the creep feeding period was calculated on a litter basis and ADG, average daily feed intake (ADFI) and gain to feed ratio $(\mathrm{G}: \mathrm{F})$ in the nursery period were calculated on a pen basis.

In both experiments, fecal color was measured during weighing in the creep feeding period, and daily after weaning until all pigs became eaters during the first week of the nursery period. The color of the feces was measured using a cotton swab as described by Sulabo et al. (2010). Briefly, a cotton swab was used to swab the inside of each pig's anus to determine fecal color; green color (from $\mathrm{Cr}_{2} \mathrm{O}_{3}$ ) during the creep feeding period or red color (from $\mathrm{Fe}_{2} \mathrm{O}_{3}$ ) during the nursery period confirmed that the pig was an eater of the feed. The pigs were categorized as eaters or non-eaters at weaning based on the fecal color during the creep feeding period for the following nursery treatments. In the first week of the nursery period (from weaning to $\mathrm{d} 7$ postweaning), feces color was used to calculate the number of days consuming the nursery diet after weaning. 


\section{Statistical analysis}

All data were analyzed by ANOVA for a completely randomized block design in the creep feeding period with model term of treatment, and for a randomized complete block design in the nursery period with model terms of treatment and replicate using PROC GLM of SAS (version 9.2; SAS Inst. Inc., Cary, NC). A litter during the creep feeding period or pen in the nursery period was used as the experimental unit. Piglet initial weight was used as a covariate for growth performance analysis between eaters and non-eaters in the HCF and LCF treatments in Experiment 2 due to a difference of initial weight between them. Least square means were separated using the PDIFF option of SAS. Statistical differences were considered significant at $\mathrm{p}<0.05$, and tendency at $\mathrm{p}<0.10$.

\section{Results}

\section{Experiment 1}

There were no significant differences in litter, piglet body weight, and ADG between the creep feed and no creep feed treatments during the creep feeding period $(p>0.71$; Table 3). Comparison between eaters and noneaters, growth performance among eaters, noneaters from the creep feed treatment, and pigs from no creep feed treatment are described in Table 4. There were no differences in piglet body weight and ADG among eaters, noneaters, and no creep-fed pigs ( $\mathrm{p}>0.58$; Table $4)$. The number of eaters and non-eaters within a litter were not different. Creep feed intake was $81.06 \mathrm{~g} /$ eater/day during the creep feeding period.

In the nursery period (Table 5), there were no differences in body weight, ADG, ADFI, and G:F ratio among no creep-fed pigs, eaters, and non-eaters, and no difference was found in the percentage of eaters in the pen during the first 3 days postweaning among the three nursery treatments $(p>0.11)$. All pigs became nursery feed eaters by $\mathrm{d} 4$ postweaning.

Table 3. Growth performance of suckling piglets in the creep feeding period (Experiment $1^{l}$ ).

\begin{tabular}{lcccc}
\hline & No creep feed & Creep feed & SEM & P-value \\
\hline Litter size, $\mathrm{n}$ & 9.33 & 9.40 & 0.41 & 0.91 \\
Piglet growth & & & & \\
$\mathrm{BW}^{2}$ at d 20 (start creep) ${ }^{3}, \mathrm{~kg}$ & 6.67 & 6.79 & 0.65 & 0.90 \\
BW at d 25, kg & 8.51 & 8.52 & 0.80 & 0.99 \\
BW at d 28 (weaning), $\mathrm{kg}$ & 9.35 & 9.32 & 0.85 & 0.98 \\
Average daily gain, g/d & 335.73 & 316.58 & 33.85 & 0.71 \\
Litter growth & & & & \\
BW ${ }^{2}$ at d 20 (start creep) ${ }^{3}, \mathrm{~kg}$ & 61.83 & 63.66 & 6.11 & 0.84 \\
BW at d 25, kg & 78.93 & 79.92 & 7.58 & 0.93 \\
BW at d 28 (weaning), kg & 86.78 & 87.32 & 7.90 & 0.96 \\
Average daily gain, $\mathrm{kg} / \mathrm{d}$ & 3.12 & 2.96 & 0.30 & 0.72 \\
\hline
\end{tabular}

${ }^{1}$ Treatments were no-creep feed ( $\mathrm{n}=3$ litters) and creep feed ( $\mathrm{n}=5$ litters). Creep feed with $1.0 \%$ chromium oxide was offered for ad libitum intake.

${ }^{2} \mathrm{BW}$ : body weight.

${ }^{3}$ Creep feed was offered from average $20 \mathrm{~d}$ of age until weaning at average $28 \mathrm{~d}$ of age. 
Table 4. Growth performance of creep feed eaters and non-eaters in the creep feeding period (Experiment $1^{l}$ ).

\begin{tabular}{lccccc}
\hline & No creep feed & Eater & Non-eater & SEM & P-value \\
\hline Piglet growth & & & & & \\
$\mathrm{BW}^{2}$ at d 20 (start creep) ${ }^{3}, \mathrm{~kg}$ & 6.67 & 6.70 & 6.91 & 0.69 & 0.96 \\
$\mathrm{BW}$ at d 25, kg & 8.51 & 8.50 & 8.50 & 0.85 & 1.00 \\
BW at d 28 (weaning), kg & 9.35 & 9.33 & 9.20 & 0.90 & 0.99 \\
Average daily gain, g/d & 335.73 & 329.02 & 286.21 & 36.80 & 0.58 \\
No. of eater per litter, head & - & 5.40 & 4.00 & 0.69 & 0.19 \\
Creep feed intake, g/eater/d & - & 81.06 & - & 3.78 & - \\
\hline
\end{tabular}

${ }^{I}$ Treatments were no creep feed ( $\mathrm{n}=3$ litters) and creep feed ( $\mathrm{n}=5$ litters). Creep feed with $1.0 \%$ chromium oxide was offered to pigs ad libitum.

${ }^{2} \mathrm{BW}$ : body weight.

${ }^{3}$ Creep feed was offered from average $20 \mathrm{~d}$ of age until weaning at average $28 \mathrm{~d}$ of age.

Table 5. Growth performance of creep feed eaters and non-eaters, and proportion of eaters in the nursery period (Experiment 1).

\begin{tabular}{lccccc}
\hline & No creep feed & Eater & Non-eater & SEM & P-value \\
\hline Body weight, $k g$ & & & & & \\
d 0 postweaning & 9.79 & 9.56 & 9.62 & 0.15 & 0.58 \\
d 7 postweaning & 10.92 & 10.20 & 10.57 & 0.27 & 0.28 \\
d 14 postweaning & 13.76 & 13.14 & 13.69 & 0.29 & 0.36 \\
d 21 postweaning & 17.99 & 17.43 & 18.28 & 0.57 & 0.60 \\
Average daily gain, $k g / d$ & & & & & \\
d 0-7 postweaning & 0.161 & 0.091 & 0.137 & 0.042 & 0.54 \\
d 7-14 postweaning & 0.406 & 0.421 & 0.445 & 0.010 & 0.11 \\
d 14-21 postweaning & 0.605 & 0.612 & 0.655 & 0.055 & 0.79 \\
d 0-14 postweaning & 0.283 & 0.256 & 0.291 & 0.022 & 0.54 \\
d 0-21 postweaning & 0.391 & 0.374 & 0.412 & 0.023 & 0.55 \\
Average daily feed intake, $k g / d$ & & & & & \\
d 0-7 postweaning & 0.320 & 0.351 & 0.342 & 0.022 & 0.63 \\
d 7-14 postweaning & 0.569 & 0.582 & 0.605 & 0.034 & 0.77 \\
d 14-21 postweaning & 0.903 & 0.959 & 0.908 & 0.015 & 0.11 \\
d 0-14 postweaning & 0.445 & 0.466 & 0.473 & 0.028 & 0.76 \\
d 0-21 postweaning & 0.598 & 0.631 & 0.618 & 0.019 & 0.53 \\
Gain:Feed & & & & & \\
d 0-7 postweaning & 0.504 & 0.255 & 0.399 & 0.099 & 0.31 \\
d 7-14 postweaning & 0.719 & 0.726 & 0.737 & 0.048 & 0.97 \\
d 14-21 postweaning & 0.670 & 0.632 & 0.726 & 0.056 & 0.54 \\
d 0-14 postweaning & 0.643 & 0.547 & 0.615 & 0.030 & 0.17 \\
d 0-21 postweaning & 0.656 & 0.593 & 0.670 & 0.037 & 0.39 \\
Percentage of eater, \% ${ }^{1}$ & & & & & \\
d 1 postweaning & 5.56 & 11.11 & 0.00 & 5.56 & 0.44 \\
d 2 postweaning & 55.56 & 50.00 & 27.78 & 7.86 & 0.13 \\
d 3 postweaning & 94.44 & 88.89 & 94.44 & 6.42 & 0.79 \\
\hline A 0 . & & & & \\
\end{tabular}

${ }^{1} \mathrm{~A}$ common nursery feed with $1.0 \%$ ferric oxide was fed to pigs ad libitum. Fecal color was measured from all pigs until d 4 postweaning on which all piglets became eaters. 


\section{Experiment 2}

There were no significant differences in litter, piglet body weight and ADG in the creep feeding period between the HCF and LCF treatments
( $p>0.47$; Table 6). Comparison between pigs categorized as eaters and non-eaters within the $\mathrm{HCF}$ and LCF treatments, growth performance among HCF eaters, HCF non-eaters, LCF eaters, and LCF non-eaters are shown in Table 7.

Table 6. Growth performance of suckling piglets in the creep feeding period (Experiment $2^{1,2}$ ).

\begin{tabular}{lcccc}
\hline & HCF & LCF & SEM & P-value \\
\hline Litter size & 9.50 & 9.33 & 0.57 & 0.85 \\
Piglet growth & & & & \\
BW $^{3}$ at d 12 (start creep) $)^{4}, \mathrm{~kg}$ & 3.86 & 3.79 & 0.29 & 0.87 \\
BW at d 16, kg & 4.96 & 4.82 & 0.35 & 0.78 \\
BW at d 19, kg & 5.82 & 5.67 & 0.40 & 0.81 \\
BW at d 25 (weaning), kg & 7.50 & 7.24 & 0.51 & 0.73 \\
Average daily gain, kg/d & 0.280 & 0.265 & 0.02 & 0.59 \\
Litter growth & & & & \\
BW at d 12 (start creep) ${ }^{4}, \mathrm{~kg}$ & 36.54 & 35.23 & 2.95 & 0.77 \\
BW at d 16, kg & 46.93 & 44.73 & 3.51 & 0.68 \\
BW at d 19, kg & 54.99 & 52.68 & 3.97 & 0.70 \\
BW at d 25 (weaning), kg & 70.91 & 67.25 & 4.92 & 0.62 \\
Average daily gain, kg/d & 2.64 & 2.46 & 0.16 & 0.47 \\
\hline
\end{tabular}

${ }^{l} \mathrm{HCF}$ ( $\mathrm{n}=4$ litters): highly-complex creep diet with fish meal, blood meal, and whey, and LCF ( $\mathrm{n}=3$ litters): lowly-complex creep diet without those ingredients.

${ }^{2}$ Creep feeds with $1.0 \%$ chromium oxide were offered to pigs ad libitum.

${ }^{3}$ BW: body weight.

${ }^{4}$ Creep feed was offered from average $12 \mathrm{~d}$ of age until weaning at average $25 \mathrm{~d}$ of age.

Table 7. Growth performance of creep feed eaters and non-eaters in the creep feeding period (Experiment $2^{1,2}$ ).

\begin{tabular}{|c|c|c|c|c|c|c|}
\hline & \multicolumn{2}{|c|}{ HCF } & \multicolumn{2}{|c|}{ LCF } & \multirow[b]{2}{*}{ SEM } & \multirow[b]{2}{*}{ P-value } \\
\hline & Eater & Non-eater & Eater & Non-eater & & \\
\hline Number of eaters, $n$ & $7.75^{\mathrm{a}}$ & $1.75^{\mathrm{b}}$ & $8.00^{\mathrm{a}}$ & $1.33^{\mathrm{b}}$ & 0.76 & 0.001 \\
\hline Percentage of eaters, $\%$ & $80.87^{\mathrm{a}}$ & $19.13^{b}$ & $85.56^{\mathrm{a}}$ & $14.44^{\mathrm{b}}$ & 6.35 & 0.001 \\
\hline \multicolumn{7}{|l|}{ Piglet growth ${ }^{3}$} \\
\hline $\mathrm{BW}^{4}$ at d $12(\text { start creep })^{5}, \mathrm{~kg}$ & 3.79 & 4.40 & 3.81 & 3.69 & 0.34 & 0.50 \\
\hline $\mathrm{BW}$ at $\mathrm{d} 16, \mathrm{~kg}$ & 5.07 & 4.94 & 4.97 & 5.04 & 0.11 & 0.84 \\
\hline BW at $\mathrm{d} 19, \mathrm{~kg}$ & 5.89 & 5.96 & 5.85 & 5.65 & 0.09 & 0.21 \\
\hline BW at d 25 (weaning), $\mathrm{kg}$ & 7.58 & 7.62 & 7.39 & 7.58 & 0.28 & 0.94 \\
\hline Average daily gain, $\mathrm{kg} / \mathrm{d}$ & 0.282 & 0.285 & 0.268 & 0.283 & 0.021 & 0.94 \\
\hline Creep feed intake, g/litter/day & 318.9 & - & 272.3 & - & 31.42 & 0.34 \\
\hline Creep feed intake, g/eater/day & 44.75 & - & 34.45 & - & 7.96 & 0.40 \\
\hline
\end{tabular}

a, b Means within the same row with different superscript letters differ $(\mathrm{p}<0.05)$.

${ }^{l} \mathrm{HCF}$ ( $\mathrm{n}=4$ litters): highly-complex creep diet with fish meal, blood meal, and whey, and LCF ( $\mathrm{n}=3$ litters): lowly-complex creep diet without those ingredients.

${ }^{2}$ Creep feeds with $1.0 \%$ chromium oxide were offered to pigs ad libitum.

${ }^{3}$ Initial body weight was used as a covariate for piglet growth performance.

${ }^{4} \mathrm{BW}$ : body weight.

${ }^{5}$ Creep feed was offered from average $12 \mathrm{~d}$ of age until weaning at average $25 \mathrm{~d}$ of age. 
Within each treatment, the number and the percentage of eaters per litter were higher than those of non-eaters $(p<0.05$; Table 7). However, no differences were found in the number and percentage of eaters per litter, and creep feed intake per litter and per eater between the HCF and LCF treatments ( $p>0.34)$. Also, there was no difference in body weight and ADG between eaters and non-eaters in the HCF and LCF treatments $(\mathrm{p}>0.21)$.
In the nursery period (Table 8), the HCF eaters tended to have greater ADG $(\mathrm{p}=0.08)$ and $\mathrm{G}: \mathrm{F}(\mathrm{p}=0.09)$ than LCF eaters in $\mathrm{d} 7-14$ postweaning, whereas the $\mathrm{G}: \mathrm{F}$ ratio tended to be lower in the HCF eaters than LCF eaters $(p=0.06)$. Body weight and ADFI were not different between treatments. No difference was found in the percentage of eaters during the first 2 days postweaning between the two nursery treatments. All pigs became nursery feed eaters by $\mathrm{d} 3$ postweaning.

Table 8. Growth performance of creep feed eaters and non-eaters and proportion of eaters in the nursery period (Experiment $2^{I}$ ).

\begin{tabular}{|c|c|c|c|c|}
\hline & HCF eater & LCF eater & SEM & P-value \\
\hline \multicolumn{5}{|l|}{ Body weight, $\mathrm{kg}$} \\
\hline d 0 postweaning & 7.53 & 7.52 & 0.01 & 0.19 \\
\hline d 7 postweaning & 8.16 & 8.03 & 0.21 & 0.70 \\
\hline d 14 postweaning & 11.71 & 11.02 & 0.29 & 0.23 \\
\hline d 21 postweaning & 15.01 & 14.74 & 0.65 & 0.79 \\
\hline \multicolumn{5}{|l|}{ Average daily gain, $\mathrm{kg} / \mathrm{d}$} \\
\hline d $0-7$ postweaning & 0.090 & 0.074 & 0.030 & 0.73 \\
\hline d 7-14 postweaning & 0.506 & 0.427 & 0.016 & 0.08 \\
\hline d 14-21 postweaning & 0.472 & 0.531 & 0.059 & 0.55 \\
\hline d 0-14 postweaning & 0.298 & 0.250 & 0.021 & 0.25 \\
\hline d $0-21$ postweaning & 0.356 & 0.344 & 0.031 & 0.81 \\
\hline \multicolumn{5}{|c|}{ Average daily feed intake, $\mathrm{kg} / \mathrm{d}$} \\
\hline d $0-7$ postweaning & 0.240 & 0.219 & 0.010 & 0.28 \\
\hline d 7-14 postweaning & 0.565 & 0.593 & 0.020 & 0.43 \\
\hline d 14-21 postweaning & 0.875 & 0.851 & 0.089 & 0.87 \\
\hline d 0-14 postweaning & 0.403 & 0.406 & 0.009 & 0.84 \\
\hline d $0-21$ postweaning & 0.560 & 0.554 & 0.030 & 0.90 \\
\hline \multicolumn{5}{|l|}{ Gain:Feed } \\
\hline d 0-7 postweaning & 0.370 & 0.340 & 0.109 & 0.86 \\
\hline d 7-14 postweaning & 0.889 & 0.717 & 0.039 & 0.09 \\
\hline d 14-21 postweaning & 0.533 & 0.623 & 0.017 & 0.06 \\
\hline d 0-14 postweaning & 0.737 & 0.616 & 0.041 & 0.17 \\
\hline d 0-21 postweaning & 0.631 & 0.620 & 0.025 & 0.77 \\
\hline \multicolumn{5}{|c|}{ Percentage of eaters, $\%^{2}$} \\
\hline d 1 postweaning & 5.56 & 11.11 & 3.93 & 0.42 \\
\hline d 2 postweaning & 77.78 & 88.89 & 10.39 & 0.53 \\
\hline
\end{tabular}

${ }^{l} \mathrm{HCF}$ : highly-complex creep diet with fish meal, blood meal, and whey, and LCF: lowly-complex creep diet without those ingredients. ${ }^{2} \mathrm{~A}$ common nursery feed with $1.0 \%$ ferric oxide was fed to pigs ad libitum. Fecal color was measured from all pigs until d 3 postweaning on which all piglets became eaters. 


\section{Discussion}

The present two studies evaluated the effects of creep feed on growth performance of pigs in the creep feeding and nursery periods, and investigated the effect of creep diet complexity on piglet growth before and after weaning.

In Experiment 1, the results showed that creep feed offered to pigs for an average of 8 days before weaning at $\mathrm{d} 28$ of age did not affect growth performance of pigs in the creep feeding period. When creep feed eaters were compared with noneaters and no creep-fed pigs no differences were observed in piglet weaning weight and growth rate during the creep feeding period. These results agree with previous studies (Sulabo et al., 2010b; Muns and Magowan, 2018) reporting that creep feeding did not increase weaning weight and growth rate in the creep feeding period. This result could be explained by low creep feed intake per eater $(81 \mathrm{~g} /$ eater $/ \mathrm{d})$ during the creep feeding period that could not result in any difference of weaning weight and preweaning growth, which agrees with Sulabo et al. (2010b).

In the nursery phase, there was no difference in overall growth performance among creep feed eaters, non-eaters, and no creep-fed pigs, which agreed with a previous study (Heo et al., 2018) that reported no difference in overall nursery performance when the creep feed was offered to pigs from d 14 of age to weaning at d 28 of age. Muns and Magowan (2018) also reported that creep feed consumption during the last 10 days of lactation increased feed intake early after weaning but did not affect nursery growth performance. This result indicates that even though creep feeding may improve familiarity of pigs with solid feed and increase feed intake early after weaning, the difference in feed intake during the first week postweaning may not be sufficient to lead to any difference in growth performance in the overall nursery period. In contrast, Bruininx et al. (2002) reported that when the creep feed was offered from $\mathrm{d} 11$ of age to weaning at $\mathrm{d} 28$ of age, the creep feed eaters had increased growth rate and feed efficiency in overall nursery phases compared with noneaters and no creep-fed pigs.
Additionally, the percentage of nursery feed eaters during the first three days postweaning was not different among eaters, non-eaters, and no creep-fed pigs. Bruininx et al. (2002) reported that the creep feed eaters started eating nursery feed approximately 2.8 hours earlier and ate more in the first 8 days after weaning than non-eaters and no creep-fed pigs. The overall nursery feed intake was not different. Although this hourly difference could not be confirmed in the present study due to the fecal color only measured by day, feed intake in the overall nursery period did not differ between creep feed eaters, non-eaters, and no creep-fed pigs. These results indicate that creep feeding had no effect to lead newly weaned creep feed eaters to consume a significant amount of nursery feed earlier than newly weaned non-eaters and no creep-fed pigs, and may not increase overall feed intake during the nursery period. Similar result was observed in Experiment 2, in which the percentage of nursery feed eaters during the first 2 days postweaning and overall nursery feed intake were not different between HCF eaters and LCF eaters.

In Experiment 2, creep diet complexity did not affect weaning weight and growth rate in the creep feeding period between eaters and non-eaters offered HCF and LCF diets, and no difference was observed in the number and percentage of eaters in litter and creep feed intake between the HCF and LCF treatments. These results agree with Okai et al. (1976), who reported that creep feeding with a highlycomplex diet did not increase piglet weaning weight, and Heo et al. (2018), who reported that the number of eaters was not affected by creep diet complexity. However, it has been also reported that using highly digestible feed ingredients in the creep feed increased pre-weaning growth rate and creep feed intake (Fraser et al., 1994; Heo et al., 2018). In the present study, due to low creep feed consumption (34 to 44 g/eater/ day) -regardless of diet complexity- preweaning performance was not affected by diet complexity. Heo et al. (2018) also reported that the effect of creep feeding could be related to feed familiarity more than to preweaning creep feed intake. 
Due to the limited number of non-eaters in each of HCF and LCF treatments in Experiment 2 , only eaters from each treatment were used in the nursery period. Growth rate, feed consumption, and feed efficiency in the overall nursery period were not affected by creep diet complexity. However, eaters from the HCF treatment tended to have greater growth rate and feed efficiency in the second week postweaning than those from the LCF treatment, even though feed efficiency was lower in the HCF eaters than the LCF eaters in the third week postweaning, resulting in no difference in overall nursery performance. A similar result was reported by Fraser et al. (1994), who found that pigs fed a highly-complex creep feed had higher feed efficiency and growth rate in the two weeks after weaning. Heo et al. (2018) also reported that feed intake in the early nursery period was higher in the highly-complex creep diet treatment compared with the lowly-complex diet, whereas overall growth performance was not different in the nursery period. Suckling piglets have an immature digestive system with high lactase activity, but low amylase and protease activities (Lindemann et al., 1986; Pluske et al., 1997). Therefore, if a creep feed is offered to piglets, whey -a lactose source- and highly digestible feedstuffs such as blood meal and fish meal may need to be included in the creep feed to help the digestive process. Therefore, these results indicate that creep diet complexity may impact early nursery growth, and creep feed may need to contain lactose sources and highly digestible feedstuffs even though its effect may disappear after the early nursery phase.

In both experiments, the creep feed offered in Experiment 1 and in the HCF treatment of Experiment 2 was a common diet, which meant that both creep feed eaters in Experiment 1 and $\mathrm{HCF}$ eaters in Experiment 2 had a familiarity to their nursery diet as they had consumed it in the creep feeding period. In spite of it, increased growth rate and feed efficiency during the early nursery period were observed only in the HCF eaters in Experiment 2, but not in Experiment 1. Therefore, this result may be attributed to the creep diet complexity, but not to the feed familiarity in the HCF eaters. In contrast, Heo et al. (2018) reported that feed familiarity improved growth rate and feed intake in the early nursery phase. Therefore, further studies may be needed to demonstrate more clearly the response of pigs to feed familiarity.

The number of eaters and non-eaters per litter were not different within the creep feed treatments in the creep feeding period of Experiment 1, which indicated that a 8-d creep feed offering before weaning may result in about half of piglets in the litter becoming creep feed eaters. However, in Experiment 2, the number of eaters were higher than that of non-eaters, which meant that a 13-d creep feed offering significantly increased the number of creep feed eaters resulting in the most of pigs (80-85\%) in the litter consumed creep feed. This result agrees with Sulabo et al. (2010b), who reported that increasing number of days of creep feed offering increased the proportion of creep feed eaters in the litter.

In conclusion, our results indicate that creep feeding may not be effective on overall piglet growth in the suckling and nursery phases, whereas creep diet complexity might affect early nursery pig growth.

\section{Declarations}

\section{Acknowledgements}

Appreciation is expressed to Heather Campbell and David James for help in diet preparation for the experiments.

\section{Funding}

This research was supported by Undergraduate Research, Scholarly and Creative Activity (URSCA)-Undergraduate Stipends and Expenses (USE) grants at University of Wisconsin-River Falls. 


\section{Conflicts of interest}

The authors declare they have no conflicts of interest with regard to the work presented in this report.

\section{Author contributions}

PKI and YDJ were responsible for the design or conception of the study, administering the project, writing, reviewing, critical reading and editing of the paper.

PKI, SEA, LGW, ALT, and YDJ were responsible for data collection.

\section{References}

Bruininx EM, Binnendijk GP, van der PeetSchwering CM, Schrama JW, den Hartog LA, Everts H, Beynen AC. Effect of creep feed consumption on individual feed intake characteristics and performance of group-housed weanling pigs. J Anim Sci 2002; 80:1413-1418. DOI: https://doi.org/10.2527/2002.8061413x

Cabrera RA, Usry JL, Arrellano C, Nogueira ET, Kutschenko M, Moeser AJ, Odle J. Effects of creep feeding and supplemental glutamine or glutamine plus glutamate (Aminogut) on pre- and post-weaning growth performance and intestinal health of piglets. J Anim Sci Biotechnol. 2013; 4:29. DOI: https://doi.org/10.1186/2049-1891-4-29

Cera KR, Mahan DC, Reinhart GA: Effect of weaning, week postweaning and diet composition on pancreatic and small intestinal luminal lipase response in young swine. J Anim Sci 1990; 68:384-391. DOI: https://doi.org/10.2527/1990.682384x

Fraser D, Feddes JJR, Pajor EA. The relationship between creep feeding behavior of piglets and adaptation to weaning: Effect of diet quality. Can J Anim Sci 1994; 74:1-6. DOI: https://doi.org/10.4141/cjas94-001

Heo P, Kim D, Jang J, Hong J, Kim Y. Effects of different creep feed types on pre-weaning and post-weaning performance and gut development. Asian-Australas J Anim Sci 2018; 31:1956-1962. DOI: https://doi.org/10.5713/ajas.17.0844

Kuller WI, Soede NM, van Beers-Schreurs HMG, Langendijk P, Taverne MAM, Kemp B, Verheijden JHM. Effects of intermittent suckling and creep feed intake on pig performance from birth to slaughter. J Anim Sci 2007; 85: 1295-1301. DOI: https://doi.org/10.2527/jas.2006-177

Lindemann MD, Cornelius SG, el Kandelgy SM, Moser RL, Pettigrew JE. Effect of age, weaning and diet on digestive enzyme levels in the piglet. J Anim Sci. 1986; 62:1298-1307. DOI: https://doi.org/10.2527/jas1986.6251298x

Muns R, Magowan E. The effect of creep feed intake and starter diet allowance on piglets' gut structure and growth performance after weaning. J Anim Sci. 2018; 96:3815-3823. DOI: https://doi.org/10.1093/jas/sky239

National Research Council. Nutrient requirements of swine. $11^{\text {th }}$ ed. Washington DC, USA: National Academies Press; 2012.

Okai DB, Aherne FX, Hardin ET. Effect of creep and starter composition on feed intake and performance of young pigs. Can J Anim Sci 1976; 56:573-86. DOI: https://doi.org/10.4141/cjas76-070

Palmer NC, Hulland TK: Factors predisposing to the development of coliform gastroenteritis in weaned pigs. Can Vet J 1965; 6:310-316.

Pluske JR, Hampson DJ, Williams IH. Factors influencing the structure and function of the small intestine in the weaned pig: a review. Livest Prod Sci 1997; 51:215-236. DOI: https://doi.org/10.1016/S0301-6226(97)00057-2

Sulabo RC, Jacela JY, Tokach MD, Dritz SS, Goodband RD, DeRouchey JM, Nelssen JL. Effects of lactation feed intake and creep feeding on sow and piglet performance. J Anim Sci 2010a; 88:3145-3153. DOI: https://doi.org/10.2527/jas.2009-2131 
Sulabo RC, Tokach MD, Dritz SS, Goodband RD, DeRouchey JM, Nelssen JL. Effects of varying creep feeding duration on the proportion of pigs consuming creep feed and neonatal pig performance. J Anim Sci 2010b; 88:3154-3162. DOI: https://doi.org/10.2527/jas.2009-2134

Varley MA, Wiseman S. The weaner pig: nutrition and management. New York (NY) USA: CABI Publishing; 2001. DOI: https://doi. org/10.1079/9780851995328.0000 